\title{
JENSEN-STEFFENSEN'S AND RELATED INEQUALITIES FOR SUPERQUADRATIC FUNCTIONS
}

\author{
S. Abramovich, S. Banić, M. Matić And J. PeČArić
}

Abstract. Refinements of Jensen-Steffensen's inequality, Slater-Pečarić's inequality and majorization theorems for superquadratic functions are presented.

Mathematics subject classification (2000): 26A51, 26D15, 26 D20.

Key words and phrases: Jensen's inequality, Jensen-Steffensen's inequality, Slater-Pečarić's inequality, superquadratic functions.

\section{REFERENCES}

[1] S. Abramovich, G. Jameson and G. Sinnamon, Refining Jensen's Inequality, Bull. Math. Soc. Math. Roum, 47, (2004), 3-14.

[2] S. ABRAMOVICH, G. JAMESON AND G. SINNAMON, Inequalities for Averages of Convex and Superquadratic Functions, JIPAM 5, (4), Article 91 (2004).

[3] S. Abramovich, M. Klaričić BaKula, M. Matić, and J. PeČarić, A Variant of Jensen-Steffensen's Inequality and Quasi-Arithmetic Means, J. Math. Anal. Appl., 307, (2005), 370-385.

[4] E. F. BECKENBACH, Superadditivity Inequalities, Pac. J. Math., 14, (1964), 421-438.

[5] L. Maligranda, J. E. PeČArić And L. E. Persson, Weighted Favard and Berwald Inequalities, J. Math. Anal. Appl., 19,0 (1995), 248-262.

[6] J. E. PEČARIĆ, A Companion Inequality to Jensen-Steffensen's Inequality, J. Approx. Theory, 44, (1985), 289-291.

[7] J. E. PeČArić, S. Abramovich, On New Majorization Theorems, Rocky Mountain J. of Math., 27, (1997), 903-911.

[8] G. Sinnamon, Refining the Hölder and Minkowski inequalities, J. Inequal. Appl., 6, (2001), 633-640.

[9] M. L. SLATER, A Companion Inequality to Jensen's Inequality, J. Approx. Theory, 32, (1981), 160-166. 